\title{
Anthrovision
}

Vaneasa Online Journal

\section{The Atlas and the Film}

Collective storytelling through soundscapes, sightscapes, and virtualscapes

\section{Cristina Grasseni}

\section{(2) OpenEdition}

1 Journals

\section{Electronic version}

URL: http://journals.openedition.org/anthrovision/1446

DOI: 10.4000/anthrovision. 1446

ISSN: 2198-6754

\section{Publisher}

VANEASA - Visual Anthropology Network of European Association of Social Anthropologists

\section{Electronic reference}

Cristina Grasseni, «The Atlas and the Film », Anthrovision [Online], 2.2 | 2014, Online since 05 January 2015, connection on 30 April 2019. URL : http://journals.openedition.org/anthrovision/1446 ; DOI : 10.4000/anthrovision. 1446

This text was automatically generated on 30 April 2019.

(C) Anthrovision 


\title{
The Atlas and the Film
}

\author{
Collective storytelling through soundscapes, sightscapes, and \\ virtualscapes
}

\section{Cristina Grasseni}

This work was supported by the Radcliffe Institute for Advanced Study at Harvard University through the David and Roberta Logie Fellowship and Radcliffe-Harvard Film Study Center Fellowship, 2011-2012.

\section{Introduction}

1 In a recent call for papers, Helena Wuff and Deborah Reed-Danahay proposed that we revisit the "ethnographic implications of storytelling engagements". They argue that, through story telling, future-making and collective pasts are placed into meaningful narratives. They underline how story-telling is "conveyed through words, sound, images and gestures" and that it is used "to create a sense of belonging among members of groups ranging from subcultures, to diasporas, to national and supranational polities". They observe that "Storytelling is visual as well as aural, and when it features in media, not least on the internet, it tends to be in mixed forms", providing "competing, contested and imaginary narratives". They conclude that "storytelling is frequently a way for a people to make sense of their past, through both memory and forgetting, while pointing toward issues of identity and morality for future generations." ${ }^{1}$ In response to this, I propose to analyze the film project that I began in 2011 as a Fellow of the Film Study Center and the Radcliffe Institute for Advanced Study at Harvard. With this project, based on based on ethnographic and audio-visual research, I set out to investigate what I called "ecologies of belonging", focusing on the collective storytelling conveyed through soundscapes, sightscapes, and virtualscapes around Italian-American religious festivals in Boston, specifically St. Anthony's Feast.

From a theoretical point of view, focusing on ecologies of belonging meant highlighting the moments of apprenticeship and performance of cultural identity as an everyday practice, part of which includes how people learn to perceive the urban environment in order to harness it to a sense of locality. I interrogated ecologies of belonging in the light 
of my previous work on skilled vision (2007): people learn to perceive in ways that remain opaque to those who do not share the same "education of attention" (to use a phrase coined by James Gibson, 1979 and amply used by Tim Ingold, 2000). For example, skilled practitioners in the medical, building, or agricultural field (just to name three out of potentially infinite fields of expertise) can tell at first sight if someone is a likely bearer of a particular illness, if a wall looks straight, or if a fruit tree has been lacking water. In more microscopic terms, seed savers select grains that "look" healthy from an organic corn cob, an engineer will scan through architectural plans to take in if the structure of a building looks sound, and an internal medicine specialist will glance at a CAT scan to divine life or death and possibly a history and a prognosis. Each of these skills are not learnt by oneself, but through repeated and socially shared acts of guided looking. In fact, what guides our looking skillfully are the authority of expert lookers (the experienced peasant, the famed surgeon, the master mason, or the schooled professional) and the other senses, which continuously orient us in "finding our way" in what would otherwise be an opaque environment, impossible to navigate.

3 As I argued elsewhere (Grasseni 2007) "skilled vision" is a learned capacity to classify and categorize, to sort good from bad, graceful from misshapen, familiar from ominous. This capacity is barred to those who do not share the same training. Such "social structures of pedagogy" (as Barry Saunders calls them in his superb ethnographic analysis of the social apprenticeship of reading CAT scans, 2008) are particularly relevant to medical schools, but are also exercised ubiquitously and multisensorially. The analytical considerations about skilled visions at work in professional and medical practice are applicable and transferrable to other ethnographic scenarios, even the most everyday and apparently banal. Skilled visions do not implicate just the use of sight, and they are not to be found exclusively within the bounded field of professional expertise. It is not just in the case of "professional vision" (Goodwin 1995) that skilled vision is part and parcel of an everyday ecology of culture. Our capacity for recognizing and classifying complex environments is a situated skill that is socially inculcated and publicly performed, even more so in moments of collective performance. The capacity to pick up and interpret sensorial cues from complex sociocultural environments is a situated practice, an everyday competence that we develop socially. Just as "skilled visions", this capacity is "collective and distributed, vulnerable and unruly, contested and evanescent" (Grasseni 2007: 7).

4 A particularly apt social realm for the study of the collective performance of skilled vision is that of festive celebrations. On these occasions, communities are built, nourished, and put on self-display while celebrating specific events or memories: religious devotion, a sportive victory, or the anniversary of a significant historical event. In this paper I focus on St. Anthony's Feast - an Italian-American religious festival in Boston. While recounting how I came to be interested in it and how I revisited it digitally, remotely and virtually over time, I use this analysis to propose ways of conducting audiovisual investigations that do not limit themselves to the recording of the ethnographic situation. I will talk about the "atlas" and "montage" as two ways of actively interrogating coevalness and the many different temporalities at play here. Remembrances both personal and collective, the festive present, and future making coexist in what I consider ethnographic film-work, namely a visual engagement that does not limit itself to the ethnographic situation. 


\section{Feasting and Reveling}

5 According to its organisers, St. Anthony's Feast attracts to Boston up to 300,000 people of the Italian diaspora over three days. They come to pay homage to the Statue of the patron Saint, but also to reclaim the streets of the gentrified North End in a festive mood. In a typical melange of public and private, religiosity and carnevalesque, St. Anthony's devotees perform several devotional actions, such as pinning dollar bills on the saint's statue, kissing the relic, or attending public mass. While reveling in public displays of devotion, participants also perform their rooting and belonging, with a lot of singing and eating, dancing and partying through the night. Audio and visual materials are posted daily on Facebook, especially around the event, but really all year round. Some come from family archives, some as personal memorabilia, often in preparation or as highlights of actual community or family events. Pervasive camera presence during the Feast, and the sharing of audiovisual souvenirs through the social network contribute to the all-yearround self-portrait as an "Italian American" community, even though few original residents are left in Boston's Little Italy.

6 The Saint Anthony Society's page on Facebook amounts to a veritable village field site, and as we shall see it allows access to otherwise invisible aspects of the feast itself. This virtual population or more than two thousand "friends" continuously produce and reproduce the Feast, placing it into a lifelong narrative of key events such as other feasts, but also family weddings, christenings, and funerals. They also bridge the geographical gaps created by an ongoing Italian diaspora - a diaspora no longer focused on reviving links between the American communities and the Italian villages of origin, but more often weaving correspondence and virtual exchanges between the North End and the current locations where many families have relocated in Massachusetts and the US, as Boston's Little Italy progressively turned into a tourist and restaurant attraction, from the original crime-ridden slum famously portrayed at the end of the 1930s by William Foote Whyte in his Street Corner Society (1943). ${ }^{2}$

7 The accompanying and collective narrative of the Feast in the social networks defines an important subset of protagonists of the Feast, often overlapping with the actual steering committee of the Feast, but including their extended families and friends ${ }^{3}$. As we shall see, the Facebook page of the Feast (St. Anthony's Feast Facebook Group Page) and other grassroots websites centered around social life in the North End ${ }^{4}$ also incorporate the documentation and the memorabilia of past generations, as well as of recently passed away protagonists, as if to keep them alive "and feasting". As a result, the making of my latest film, "Christmas in August" with Federico De Musso entailed a number of methodological issues about how to tap ethnographically into the multiple voices that emerge from these social networks, where a daunting repository of "found footage" amounts to a veritable form of collective storytelling.

8 This is in fact "re-found" footage, because it has already been "found" by someone, who puts it on line and imbues it with a precise meaning in the context of a specific collective engagement. In this sense "found footage" becomes a contemporary cognate of the previously investigated category of the "home-movie". As Richard Chalfen argued of home movies in 1986: "The people who came together to be 'in' a home movie shall stay together in a symbolic sense, in a symbolic form, for future viewings. The home movie collection can be understood as a visual record of a network of social relationships that 
are not easily lost when people grow up, move away, or die" (p. 107). In fact, the type of re-found footage that we see on social networks is largely the result of plundering audiovisual souvenirs that were shot in the "home mode of visual communication" - to quote Chalfen's expression - with the clear intent to share them in a circle of "friends" in the Facebook meaning of it.

Re-found footage and photographic family portraits shape the shared imaginary surrounding St. Anthony's Feast, setting the tone for place-making and belonging, as soundscapes and visual culture are performed in the guise of popular religiosity. As we shall see, following the Saint's Facebook page allows one to trace the contours of collective remembrance and forgetting, including ethno-musicological lineages and elaborately choreographed soundscapes that remind us of the Naples of neorealist cinema, but also of the "kinesic" analyses of De Jorio in the $18^{\text {th }}$ century, and of the more recent research by Diego Carpitella, an Italian ethnomusicologist who studied "cultural cinesics" in Naples in the 1970s.

I was alerted to the importance of this virtual collective imaginary when I found a tribute to a recently deceased member, Mr. L.F., on the Facebook page of St.Anthony's Society just a few days before the Feast which took place in August 2011. This carefully edited video placed him squarely amongst the Feast organizers and protagonists of several previous editions. A musical photo-show cast him over the years, as he is interpreting a role that recalls a key figure in Southern Italian folklore, the pazzariello. This is a kind of carnevalesque town crier, best known from its cinematographic impersonation by the Neapolitan comedian Toto in Vittorio De Sica's L'Oro di Napoli (1954), Mr. F.'s persona was most probably a very personal appropriation of tropes and costume features of the pazzariello - including the baton and the white gloves. Maybe such tropes had in turn become known to him through social media - Italy having long ceased to be the authenticating principle for Italian American devotional folklore.

11 I never met Mr. F., nor further investigated in how he came to be a pazzariello-like figure. In the two following editions of the Feast that I observed, I did not see a substitute for him. But through the public posting of this tribute I could obtain a general confirmation what my fellow ethnographer Katia Ballacchino had already found of Nola and New York, namely that Southern folklore is constantly and playfully appropriated and adapted to new contexts, tools, and tropes. The Italian ethnomusicologist Diego Carpitella, who worked with Alan Lomax and studied specifically Naples street festivities in the 1970s among other selected examples of "demo-kinetic codes", believed in the possibility of tracing an archeology of such codes, in the case of Naples, from the ancient Greek colonies to contemporary Neapolitan folklore (1981). In his film Cinesica Napoli, Carpitella used as a reference point the catalogue of gestures that the antiquarian and Canon of Naples' Cathedral Andrea De Jorio collected in the early $19^{\text {th }}$ century (de Jorio 1832). De Jorio believed that Neapolitan gestural semiotic maintained vestiges of the dramatic body language of the Ancient Greek colonies of the Magna Grecia ${ }^{5}$. Working thirty years before, David Efron had comparatively analyzed gesticulation among Neapolitan and Sicilian immigrants and Jewish immigrants from Poland and Lithuania in NYC, coming the conclusion that the differences in conversational gestures were certainly not symptoms of racial aesthetics but of a dynamic adaptation of cultural kinesthetic codes to new environments and contexts (Efron 1941). Deidre Sklar (2008) revisits this study to propose that we "conceptualize 'thinking' in different cultural communities as different genres of 
'choreographic' improvisations whose structural rules can also migrate, organizing and reorganizing sensory modalities, formal elements, and vitality affects" (p. 101).

What I am interested in here is not trying to validate folklore genealogies, nor deconstructing racial identities that have been amply deconstructed already - but rather offering contemporary examples of the kaleidoscopic possibilities of self-casting in stereotypical terms, by publicly performing a set of recognizable cultural traits. The joker man-like figure of the pazzariello offers a clue about the kind of heterogeneous legacy that connects communities and imaginaries across time, which Jacqueline Andall and Derek Duncan, in their study on Italian Colonialism, have called "displaced memories" (2005: 10). We can think of them as "traces, tidemarks and legacies" (from the homonymous theme for the 2012 American Anthropological Association Conference), which are actively deployed and re-appropriated in storytelling engagements.

The film "Christmas in August" focusses on the Feast, which takes place every August and during which returning residents and their kin pay homage to the patron Saint, but also claim national and even regional roots and perform a partly self-assigned collective identity. The Feast is immersed in the familiar urban landscape of Boston's North End, an immersion facilitated by the constant (and loud) soundscape of brass bands, marching bands, cheering bands that accompany the procession and enliven the event, as well as the amplified soundtrack of culinary stands, street vendors and dancing stages. The film plays with the process of familiarization and estrangement from such landscapes and soundscapes, especially when it becomes clear that they embed unexpected fragments and layers that hark back to the Italy of the Fascist regime of the 20's and 30's - as we shall soon see.

The film combines interviews filmed on location with ethnographic footage and archive material from authorized sources in the social network. ${ }^{6}$ The Facebook group, pervasive camera presence during the Feast, and the sharing of audiovisual souvenirs through the social network contribute to the all-year-round self-portrait as an "Italian American" community. In figures 1-5 I focus on the ubiquitous role of photographic and film cameras at the Feast (figure 1), on the theatrical display of the saint's statue as it is paraded along the North End street covered with dollar bills (figure 2), and on the patriotic assumptions of much of the artefacts displayed, sold, or used as urban decoration for the event (figure 3). 
Figure 1. Camera presence

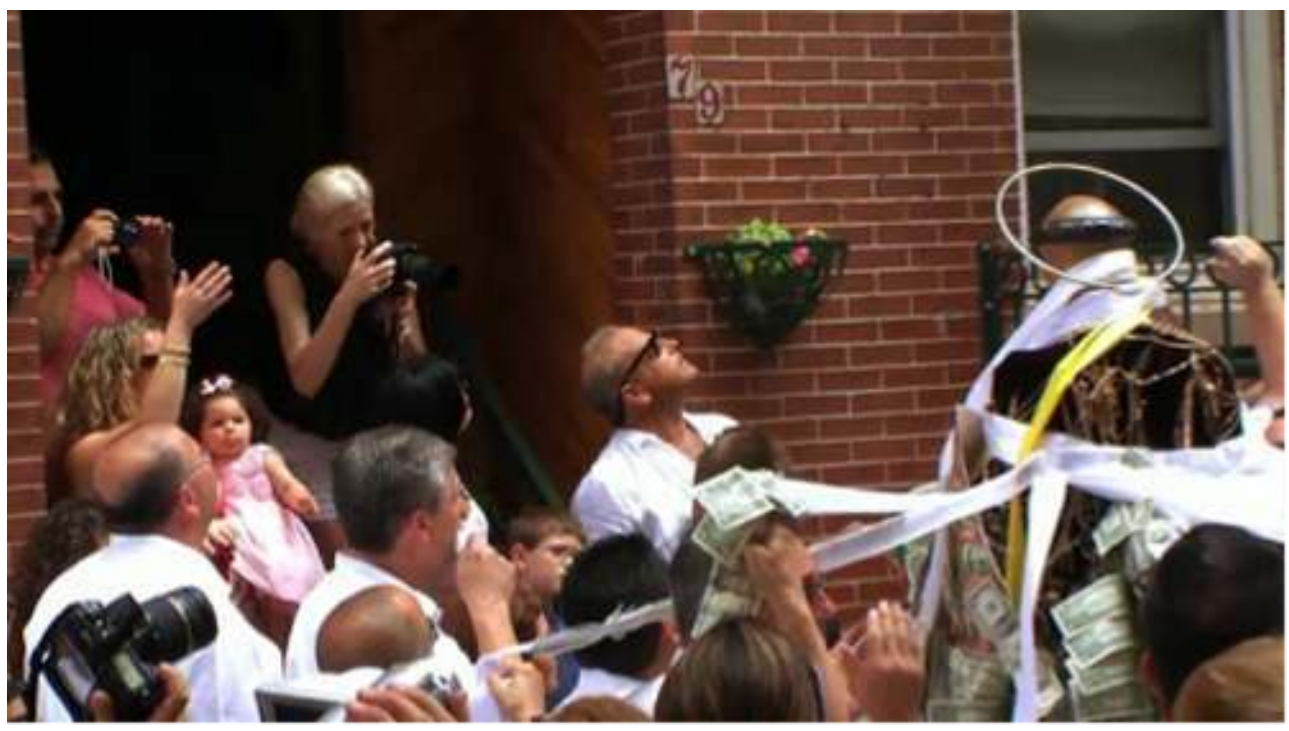

Residents, procession participants, and statue carriers wait for an elderly lady to lower a garland of dollar bills to be laid on the Saint from a window above them. In the meantime, under her balcony everyone prepares to take a photo shot of the moment. Boston, August 2011.

Photo by Cristina Grasseni

Figure 2. "The Saint is full!"

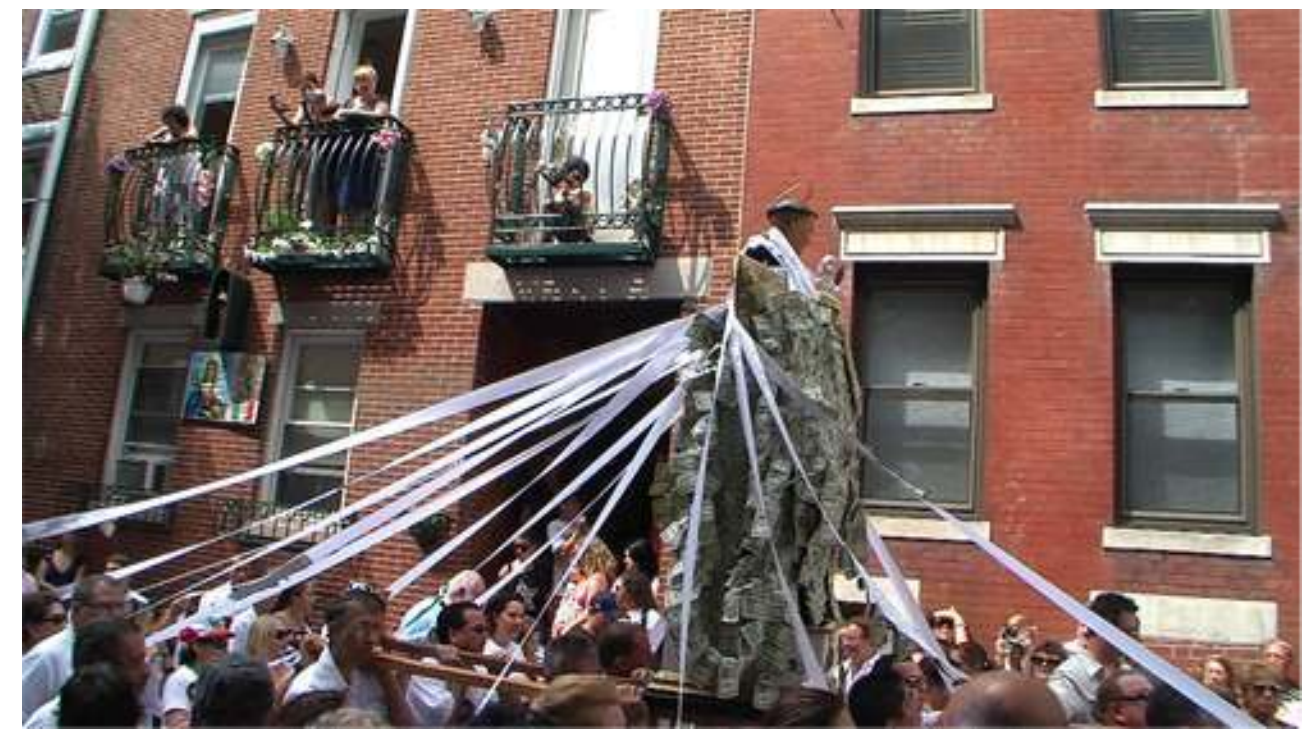

The Saint's statue moves away and progresses in the procession, entirely clad in dollar bills. Boston, August 2011.

Photo by Cristina Grasseni 
Figure 3. Public exhibition of the statue

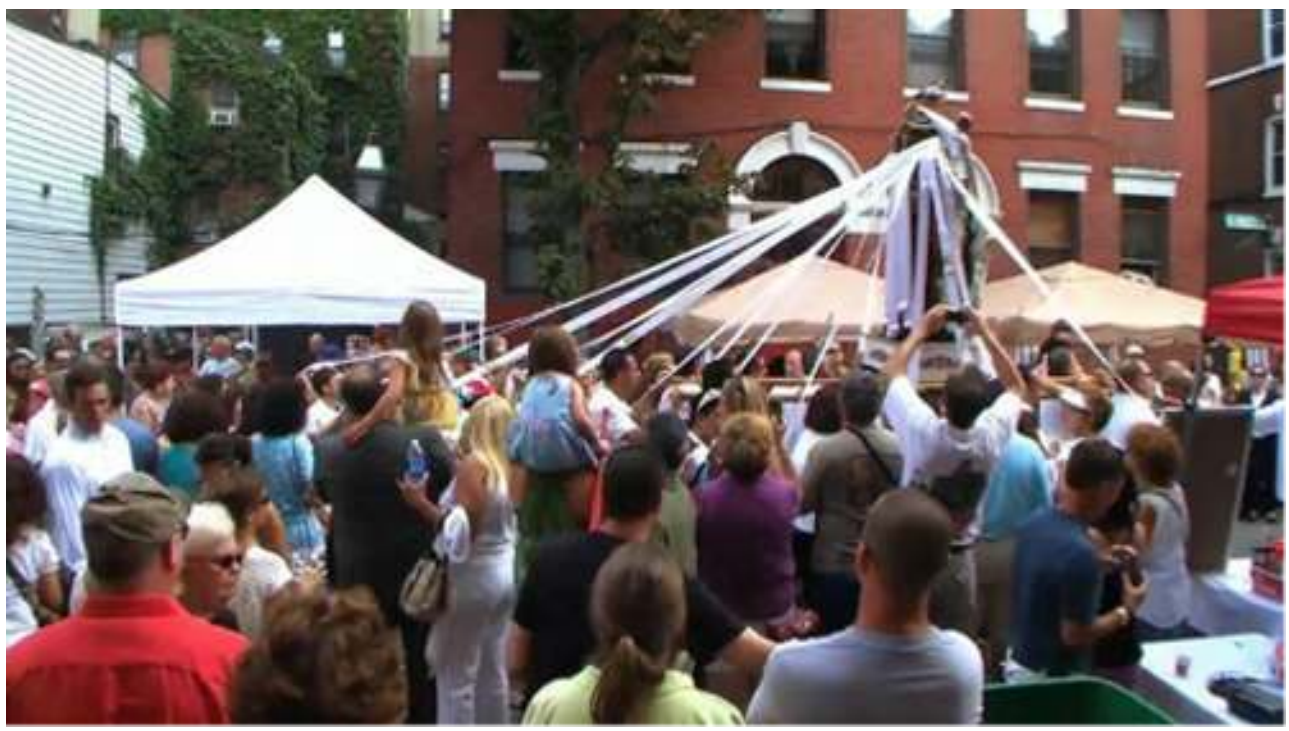

An earlier moment, as the statue is kept on display during a public Mass, which is held directly in the street. Boston, August 2011.

Photo by Cristina Grasseni

Figure 4. Urban décor

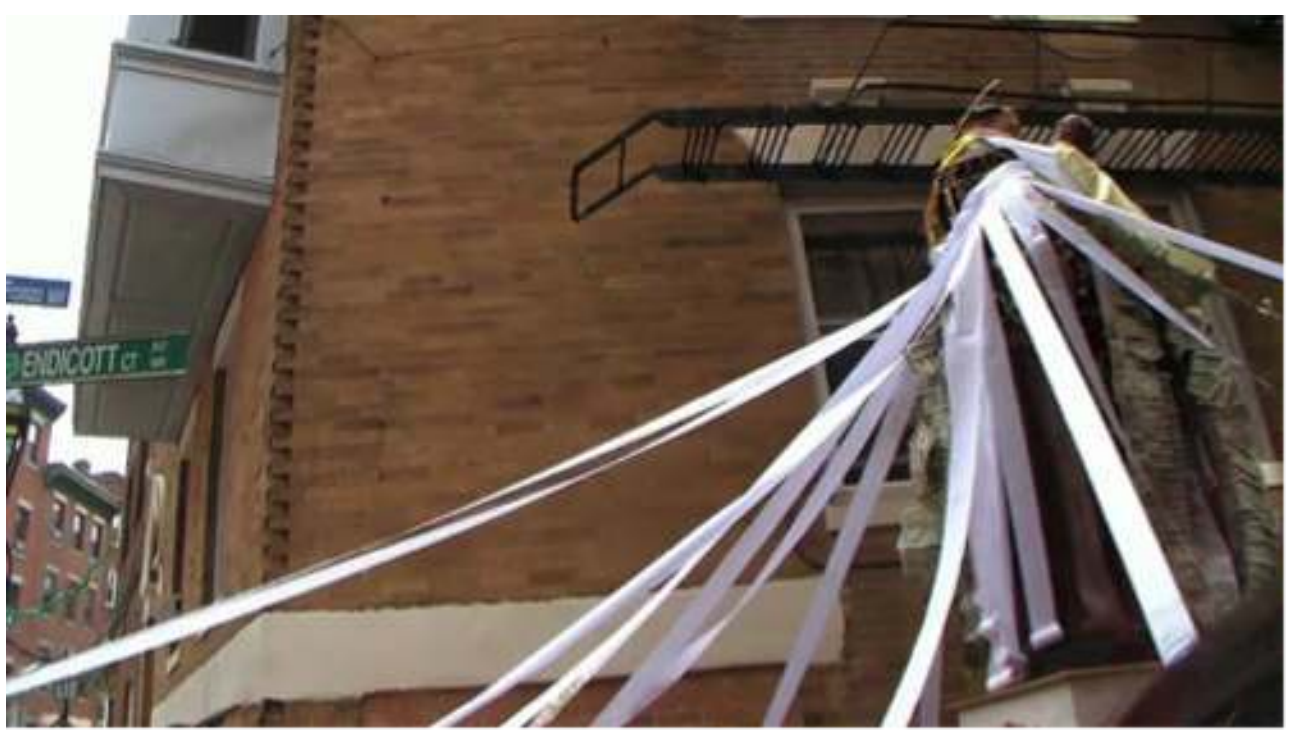

Long white stripes are held by the Feast committee members accompanying the statue during the procession, to "dress" the Saint and facilitate pinning dollar bills on the go. Boston, August 2011.

Photo by Cristina Grasseni 
Figure 5. Patriotic confetti

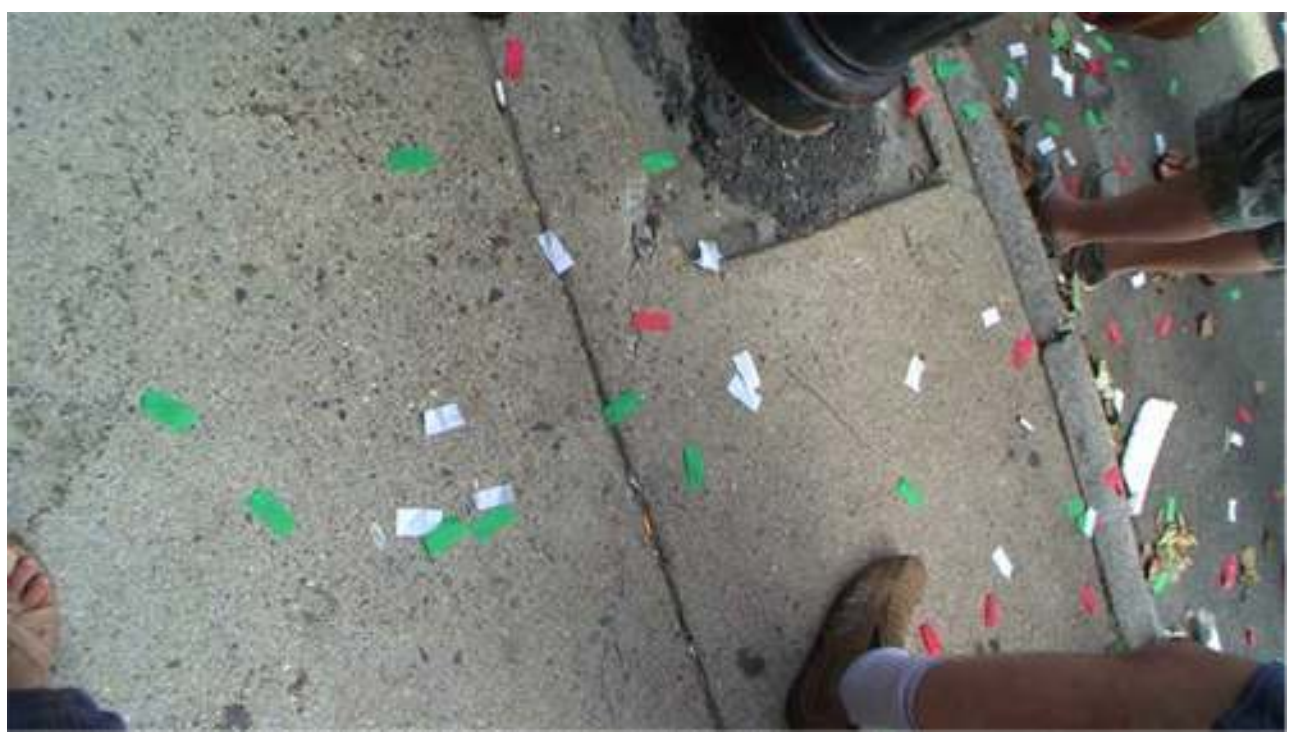

Confetti in the colors of the Italian flag (red, white, and green) are abundantly cast from windows and rooftops at the passage of the Saint. Boston, August 2011.

Photo by Cristina Grasseni

15 I became particularly interested in how the participants produce, interpret and share very specific interpretations of very specific musical, ritual and material repertoires during the Feast - and how they account for it. In a moment around minute 20 of the film, you see me debating with Jason, previous President and Trustee of St. Anthony's Society at the time of filming, about the fact that the marching band includes fascist songs in its repertoire during the procession of the Saint.

\section{Videoinsert 1: Christmas in August}

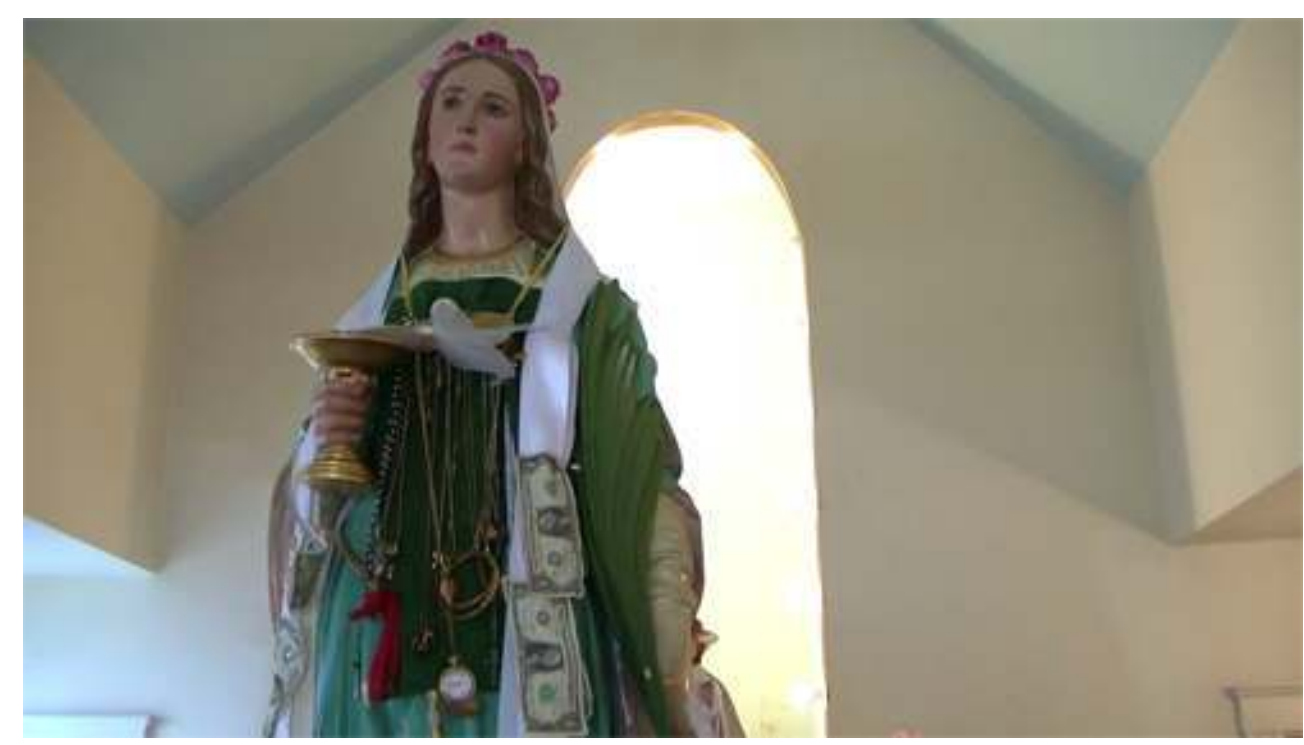

De Musso, Federico and Grasseni, Cristina 2013. Christmas in August. Boston's St. Anthony's Feast. Video, 30 mins. Click here to watch video: https://vimeo.com/63213733 
In particular I point out that the song that I happened to capture in my footage is Faccetta Nera, which means "Little Black Face". This was a colonial song accompanying the Italian army in the invasion of Ethiopia in 1936. It was regularly sung in the mandatory weekly rallies of the Fascist Youth Association, which gathered all males and females between the age of 8 and 18 from 1926 to 1943. For this very reason, it could never be played in public, in Italy, let alone at a religious festival, if not for incendiary purposes or at neo-nazi rallies. ${ }^{7}$ Nevertheless, being commonly sung as a popular motif (together with other songs such as Giovinezza, "a Hymn to Youth"), it did become part of a folk repertoire of sorts of the period. In fact, the fascist regime self-consciously invested on popular culture and popular music as a means of naturalizing the population from the earliest age into the totalitarian regime - its values, its myths, its rituals and icons (De Grazia, 1981 and 1992). Many elderly women born in the early 1930s may well reminisce about these songs in the rosy light of childhood's memory. And so, I would presume, does the old lady who, shedding tears, bestows a garland of dollars on the Saint from her balcony, while the boy whom I imagine to be her grandson liberates a flock of white balloons falling on the crowd - as in the relevant scene of Christmas in August.

In the film, I elicit a reaction from Jason about this particular scene captured on footage, and he confirms that "yes, it's a fascist song"! But he also adds that the Roma Band plays a repertoire that became more or less fixed in the Thirties. The Band still petitions the saint with songs, each song being associated with a street corner and with a particular family which used to request that song, even after the family has moved away. The band retraces the boundaries of a soundscape that no more matches the now gentrified landscape of Boston's Little Italy, where Jason recalls playing "saint" all year round with his pals, mimicking the procession with the statue and the marching band with other children in the streets. Listening to Jason, we plunge into a hidden topography of lost presences, of grown-up children and their present gendered performance, of family-based, regional, or patriotic nostalgias- all of which guide the procession of the saint, winding its way through alleys and cul-de-sacs, marching band in front, over a good six to nine hours, depending on the crowd. This complex form of orientation through soundscapes, landscapes and memories is embodied in the figure of the procession leader - Jason himself in this case - who knows which songs belongs to which street corner.

\section{Ecologies of belonging between the Atlas and Montage}

18 Jason's reminiscing about the new role played by fascist songs within the context of Italian Americans feasts allows me to dwell on what I call "ecologies of belonging". A critical analysis of ecologies of belonging is the theoretical agenda of developing an ethnographic and critical focus on the apprenticeship and performance of culture, identity, and locality as an everyday practice. The skilled perception of the urban festive environment, as this anecdote proves, is not just about sight, sound, and the recognition of shared cultural symbols (such as that of the saint's statue itself). On the one hand, the Feast would have been opaque to me had I not been previously exposed both to the notion and to the practice of walking a patron saint's statue in a procession (see Grasseni 2009: 58-61). The tradition of pinning bills on the saint was foreign to me personally, but not unknown through relevant literature on devotional practices. In any case it did not 
stir any sense of the exotic: there is a Catholic tradition of honoring the icon of a devotional figure, a protective ("patron") saint with riches of metaphorical and literal currency (from the white ribbons, to the painted crown, to actual jewels or money). This falls within a wider votive culture (from the ex-voto, namely material tokens of one's 'vote', namely a promise to one particular saint or the Virgin Mary, as a sign of gratefulness for a grace perceived or petitioned: see Faeta 1986).

My own recognition of Faccetta Nera in the streets of Boston, though, jarred with this familiar visual ensemble and was an example of "skilled listening" rather than of "skilled vision" - I could recognize the melody, and was disoriented because I could not match the context with the item. Only in a second moment this recognition became a reflexive ethnographic interaction and document, when I and Jason discussed about my footage of this event and I captured such conversation on camera. This triggered references to other similar events during which a politically charged and historically defined song is adapted to the festive soundscapes of Italian Americans' remembrances about a place of their own - which is not Fascist Italy, but contemporary America. In other words, Faccetta Nera is a sediment in a "media archeology of place", to use an expression coined by Lucien Taylor, Ernst Karel and Jesse Shapin in their work at the Harvard Sensory Ethnography Lab. ${ }^{8}$ In the film, Jason recognizes the ambivalence of this heritage and "tells me a little story" about it to deflate its potential embarrassment: "old timers know", but for most people this is just one nostalgic piece of soundscape like any another, and in any case " it was such a long time ago".

The Italian Anthropologist Augusto Ferraiuolo (whom you see in the video) described in his recent monograph (2009), how Italian religious festivals become catalysts for a multigenerational and diverse Italian community, which reconnects and rallies around prominent community leaders9. Following Michael Herzfeld's notion of "Cultural Intimacy", I view the scene with Jason, and indeed the mise-en-scéne of Faccetta Nera under the windows of the elderly lady crying in a surge of emotion as her family uncoils the roll of dollar bills to be lavished on the Saint's statue, as a theatrical display of complicit intimacy. By that I mean the depth of field of social context and social memory that one needs in order to decipher this festive and emotional landscape, which amounts to a collective storytelling engagement. To correctly interpret the clues and symbols that are on kaleidoscopic display one needs to recognize pivotal moments - such as this - in the day-long procession and widespread celebration. This is a complex social capacity that depends on timescapes as well as landscapes and soundscapes. Michael Herzfeld (2005) says that "Cultural intimacy may erupt into public life". "This can take the form of ostentatious displays of alleged national traits ... these are the self-stereotypes that insiders express ostensibly at their own collective expense... the forms of rueful selfrecognition in which people commonly engage". In the interviews and feast footage, I sought to capture some examples of such ostensible self-ascription of a national (even ethnic?) categorization as "Italians", played out through familiar soundscapes and popular religiosity.

21 The fact that the Feast is actively engaged into collective storytelling - the materiality, durability, and circulation of the recordings of the Feast - is equally important as its performance. For instance, connections and alliances between "Societies of Saints" are celebrated and performed, both within the North End and between Boston and the original Feast in Italy, often directly in the social networks through the sharing and tagging and bookmarking of videos, photographs or sets of popular songs. Katia 
Ballacchino has followed the respective borrowings and compared the evolution of the Festa dei Gigli from Nola near Naples, and its appropriation through migrants in Italian American communities in New York City. ${ }^{10}$ St. Anthony's Feast is itself "twinned" with the original site of this devotion, Montefalcione in the province of Avellino.

Across the physical and virtual communities, social memory provides a wide spectrum of experience whose many strands overlap and intertwine, as in Wittgenstein's' metaphor of the many threads spliced into a rope, all together amounting to a Family resemblance. ${ }^{11}$ As anticipated above, the act of levying dollar bills on St. Anthony's statue fits in a well known repertoire of devotional folklore, which in many parts of Southern Italy prescribes competitive monetary and jewelry gifts being publicly bestowed on the saint as a substantive sign of one's participation in and accountability to the community - even though nowadays and in Boston the Saint's treasure is only partly employed to fund the following Feast. ${ }^{12}$.

Using social networks materials profusely in the editing of the film, I and the film editor, Federico De Musso, followed the principle of montage rather than that of observational film-making ${ }^{13}$ to render a kaleidoscopic mesh of links and quotes that one encounters across the virtual and physical communities. During the shooting of the interviews I strive to reproduce an atmosphere of friendly chat and reminiscence, getting in and out of the frame, with the complicit presence of fellow anthropologist Augusto, who is well known in the Society's circle, and making use of footage elicitation. Through montage, we linger instead on the conscious ironies of self-sterotypization, on the tension between the self-representation of the Feast as a friendly gathering and the political sedimentations of the "patriotic" songs, the militaristic hierarchy within and between marching bands, and the socially performed roles of society members, feast organizers, and cheer leaders.

The film was actually conceived as part of a wider project on critical ecologies of belonging, skilled vision, and self-stereotypes..$^{14}$ The overall methodological idea of the project, in fact, was to contextualize the film within an "atlas", namely a repository of the traces, lineages and poignant presences of recurrent tropes about racial and ethnic (self)identification, of which the Italian American experience could be just one exemplary case. An atlas, in the sense given to it by Aby Warburg, should at once gather heterogeneous materials and provide a perspicuous overview of their reciprocal relations. By definition the atlas is something that can be dynamically interrogated (Bruno 2002) rather than an objective collection of documents or an unfolding linear narrative. As is well known, Warburg's pathological obsession for mapping the pathways of culture $^{15}$ resulted in a powerful epistemological idea, that of tracking the journey of images across collective imaginaries and through history (Mc Ewan 2006). Mounting photographs of artworks, commercial art, even playing cards and stamps on canvascovered wooden panels, Warburg collated what he considered to be pertinent traces of an "afterlife of antiquity" in the Renaissance and Reformation, thus building his Mnemosyne atlas in the late 1920s (Spinelli 1998). In this unfinished project, he juxtaposed philologically incommensurable objects such as scrapbook drawings, postcards, carpets, and objects of popular art (Warburg 2003). As noted by Matthew Rampley $(1999,2000)$, both Walter Benjamin and Aby Warburg used the "atlas" as cognitive tool, one in high art and the latter in the analysis of the aesthetics of everyday life. ${ }^{16}$

For me, the Atlas was a conceptual map to imagine an inventory of potentially redundant, overlapping and divergent "visual arguments". With this in mind, I worked with a developing software for digital annotation (Worktop) to archive, freeze, replay, select, 
highlight and link with one another frames and clips in footage, snapshots, scholarly article, website pages, etc. ${ }^{17}$ I created several "visual nodes" or arguments as illustrated in figures 6-13. In this database I tagged the items, inserted text comments, referred back to literature, magnified or moved around details and items as I analyzed and connected them. The Skilled Visions database worked for me as an "Arcade" of visual arguments, a prototype of a potential digital Warburg-like "atlas" of visual arguments - each nodes being an argument that assembled sources from films, videos, stills, texts, and similar materials both from scholarly archives and from social networks. It was a work-top to play with linkages and comparisons, connections and affinities, on an audio-visual rather than on a purely word-driven basis.

\section{FIGURE 6. Database home}

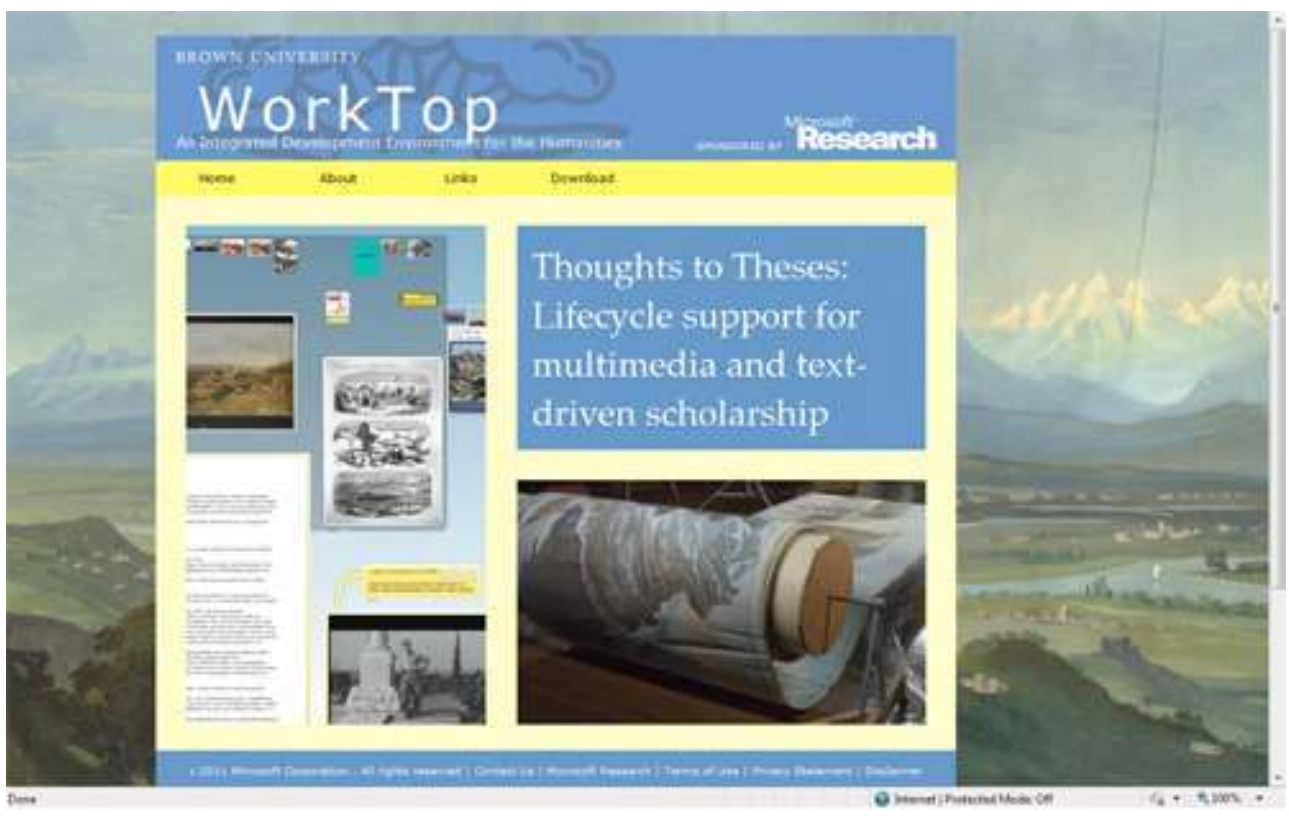

My Skilled Visions Database was housed on WorkTop at Brown University http://cs.brown.edu/research/ptc/worktop/index.html 
Figure 7. A workflow demo

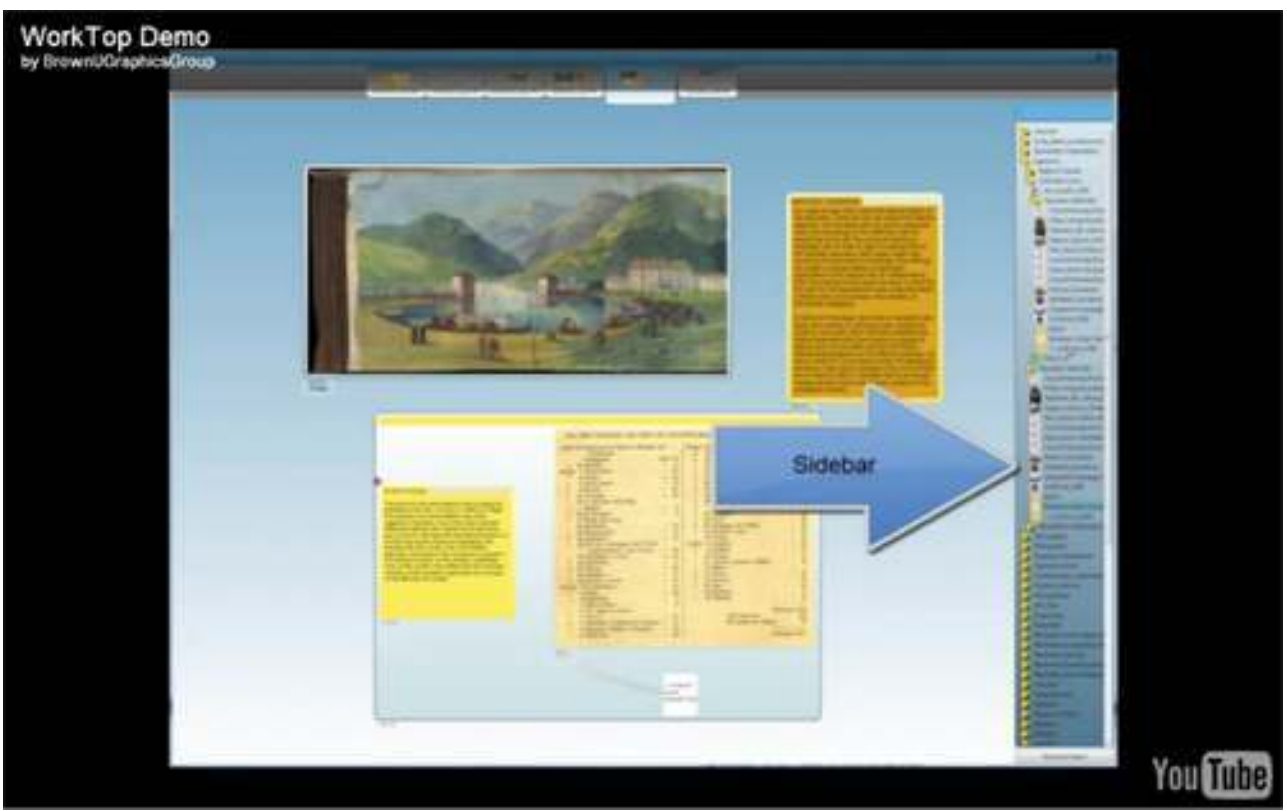

WorkTop was a "document-centric" database. A Demo is available on Youtube in which the programmer, Bob Zeleznik lists the features available

http://www.cs.brown.edu/ bcz/worktop/about.html 
FIGURE 8. Visual arguments

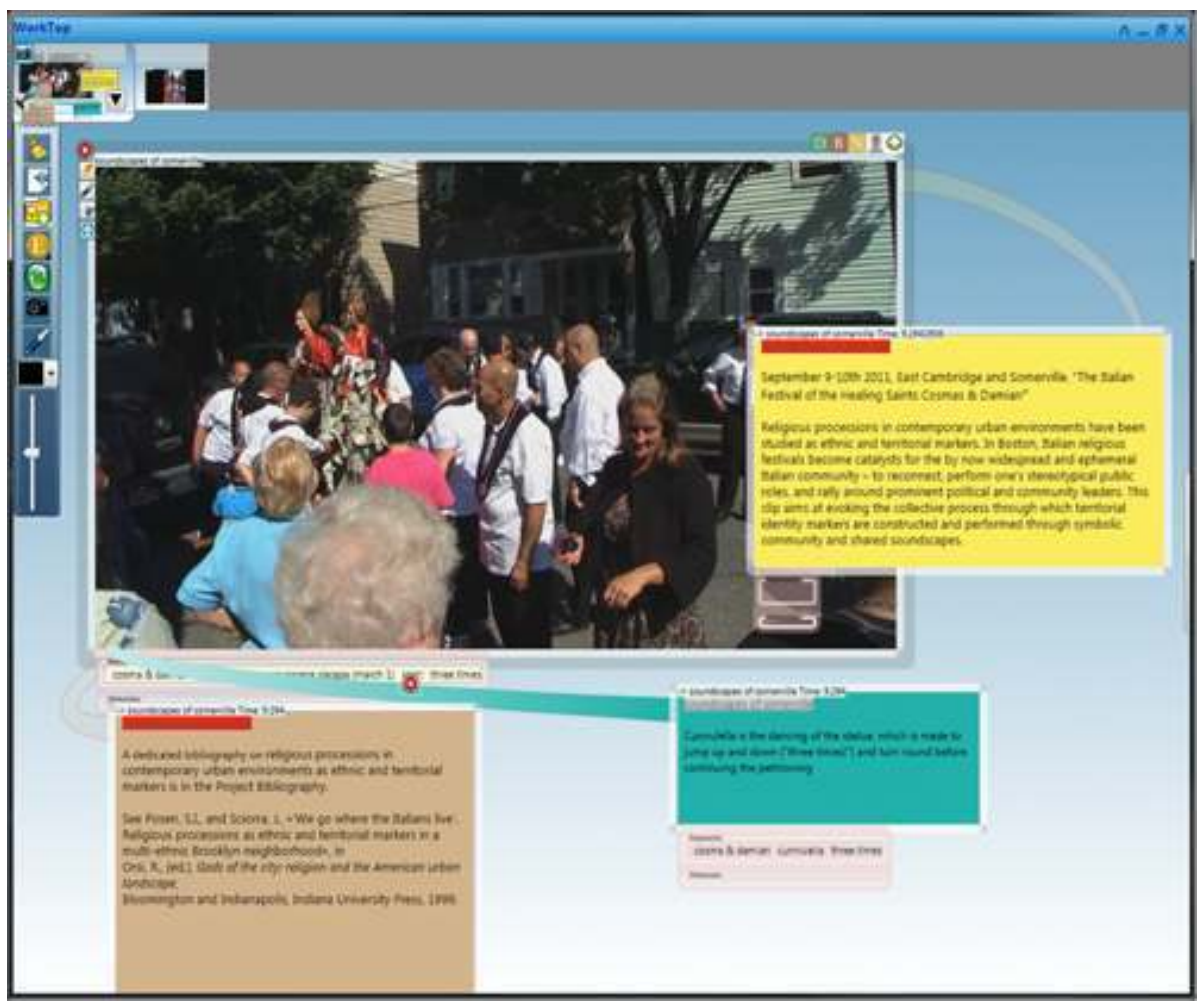

In the Skilled Visions database, I organized "Visual Arguments" into as many 'snapshots' that could be viewed like as many pages in an 'Atlas'. They could be recalled by the top bar. By clicking onto any one of the Visual Arguments (such as Pazzariello, Mughshot Aesthetics, Soundscapes of Somerville, or Colorblind for instance) one would enter a workspace populated by documents: videoclips, PDFs, websites, my own annotations and bibliographic references, as well as a number of connections between them, in the form of colorful "snakelike" arrows.

Screen snapshot by Cristina Grasseni 


\section{FIGURE 9. Snapshots}

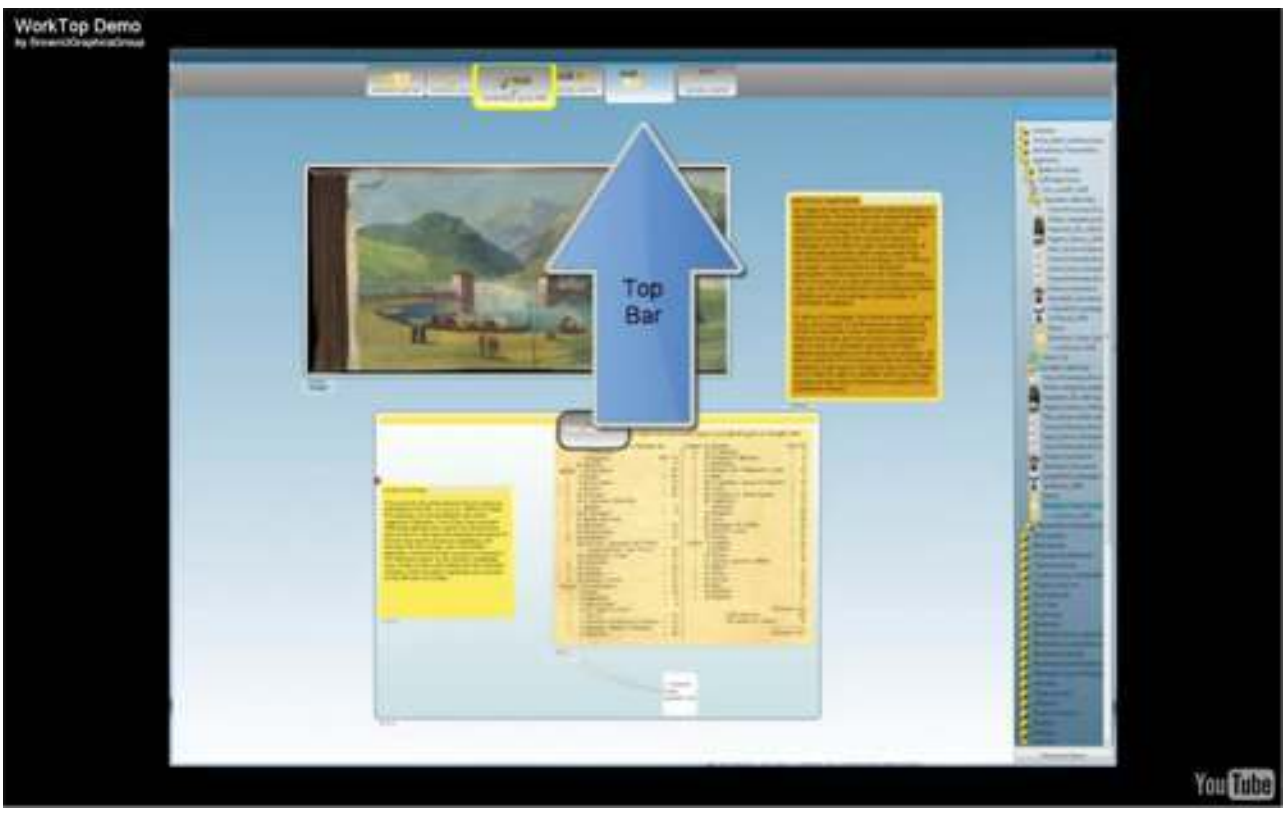

The demo illustrates how it is possible to create a (potentially infinite) series of "visual nodes". One could create new visual nodes or pages by clicking in the "new workspace" area in the top bar. This would open a clear canvas onto which one could either "drag in" existing documents from the digital archive stored on the server (sorting them from the sidebar on the right), or import new documents, for instance through a live URL or from one's desktop. A blue canvas is the current workspace. By right-clicking in the middle of the workspace one is prompted for importing a URL address or otherwise for browsing for a document to import.

http://www.cs.brown.edu/ bcz/worktop/about.html 


\section{FIGURE 10. Annotating}

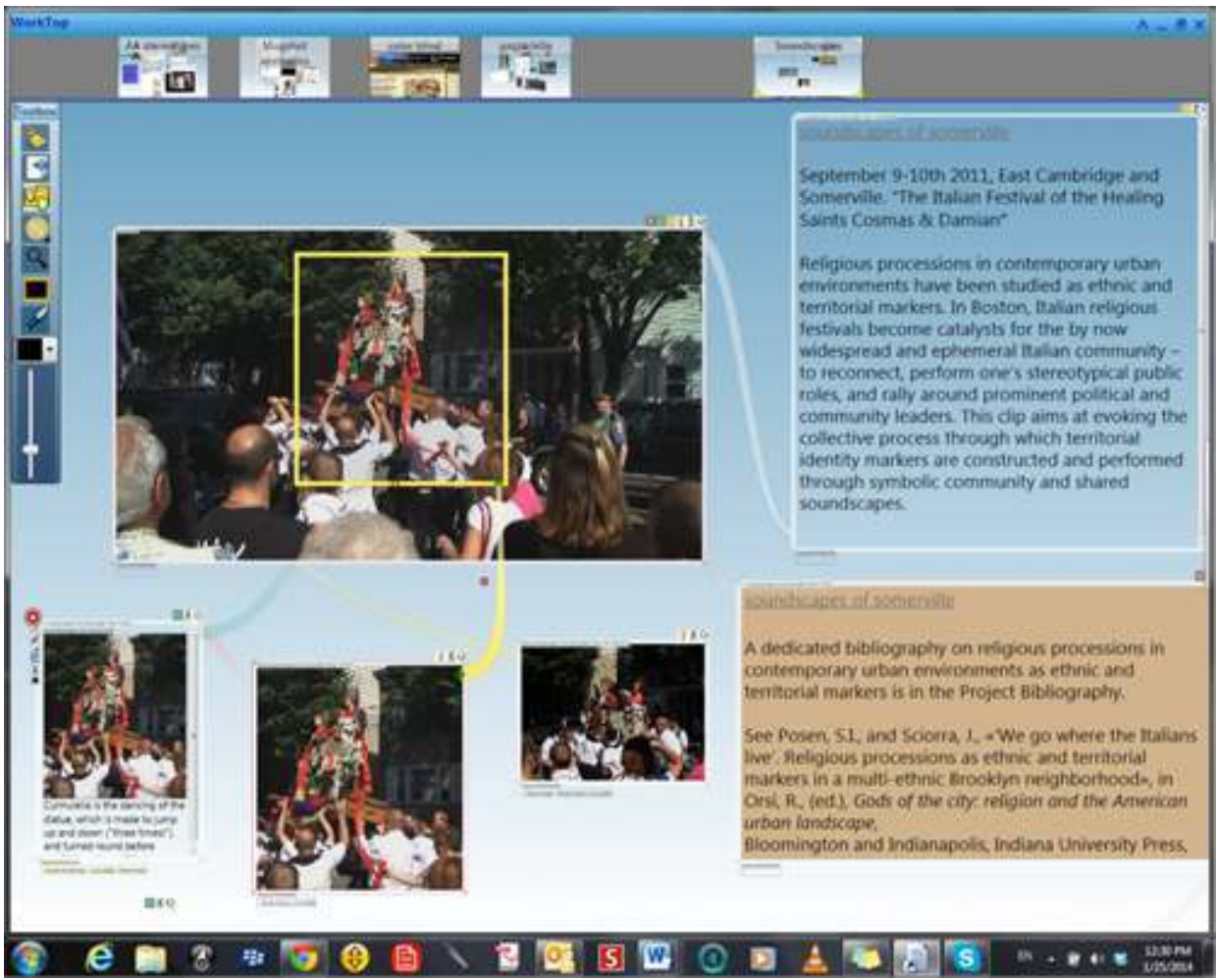

One could add new annotations to an existing (or previously annotated) document by clicking on the green cross that appears top right in every framework of every document. This button allows to Drag and Drop a new Annotation Bubble. One could choose what type of annotation this would be: a note, description, summary, bibliographic reference, visual source, or simply highlighting a link (these are my own customised choices for types of annotation).

Screen snapshot by Cristina Grasseni 
Figures 11, 12 and 13. Highlighting

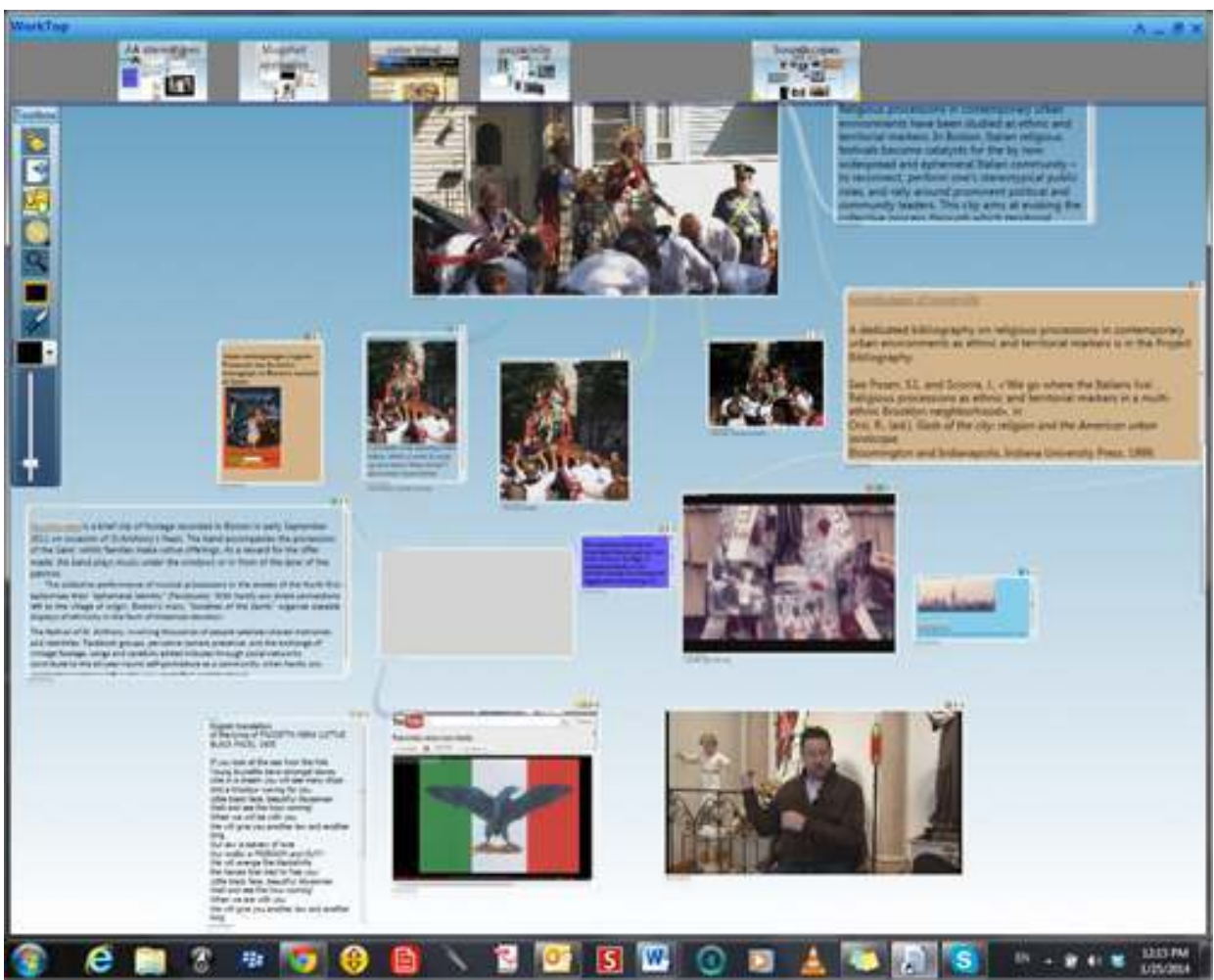

One could highlight a portion in a text, still image, playing video or live web page and create an icon with an accompanying text. All hyperlinks created between annotation "bubbles" and imported documents were bi-directional: clicking on one end brings up the other. Here one can see me first making connections (figure 11) between Jason speaking and a number of features of the Boston feast, such as its closeness to other patron saint feasts that are celebrated all around the Boston area and its link with other big feasts on the East coast, such as the Gigli Feast in NYC studied by Ballacchino (figure 12). Then I finally "zoom in" in the issue of Faccetta Nera: using its audio file available on Youtube, its original lyrics as found on the internet and and my translation into English (figure 13)

Screen snapshot by Cristina Grasseni 
Figure 12. Contextualizing Christmas in August

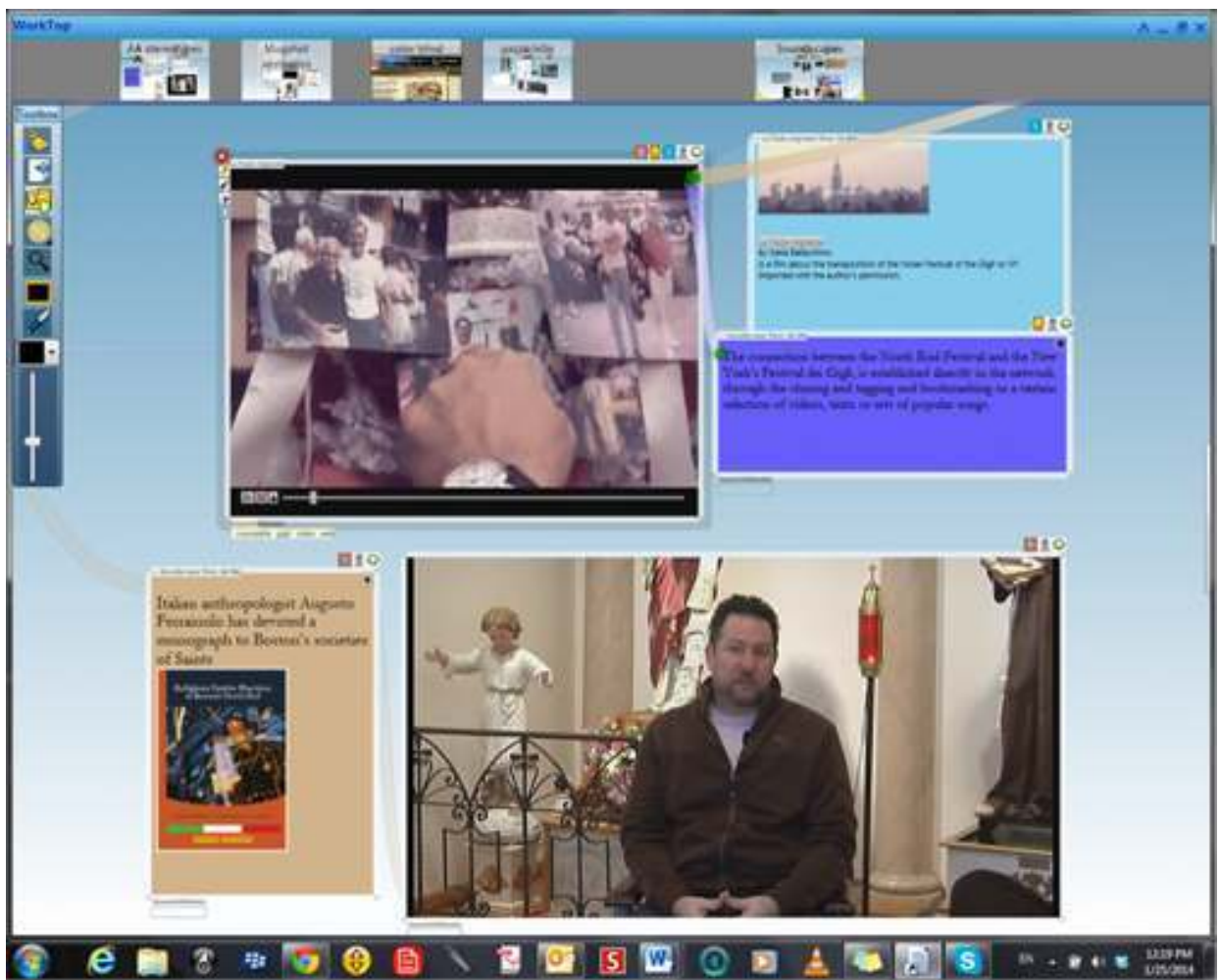

Footage of Christmas in August, book by Augusto Ferraiuolo, film by Katia Ballacchino and my links and annotations. The films could play in Worktop and could be stopped and annotated in the frame at any point. Online printed sources could be consulted, freezed and annotated live in Worktop or dragged in from my repository (for example a PDF of a journal article).

Screen snapshot by Cristina Grasseni 


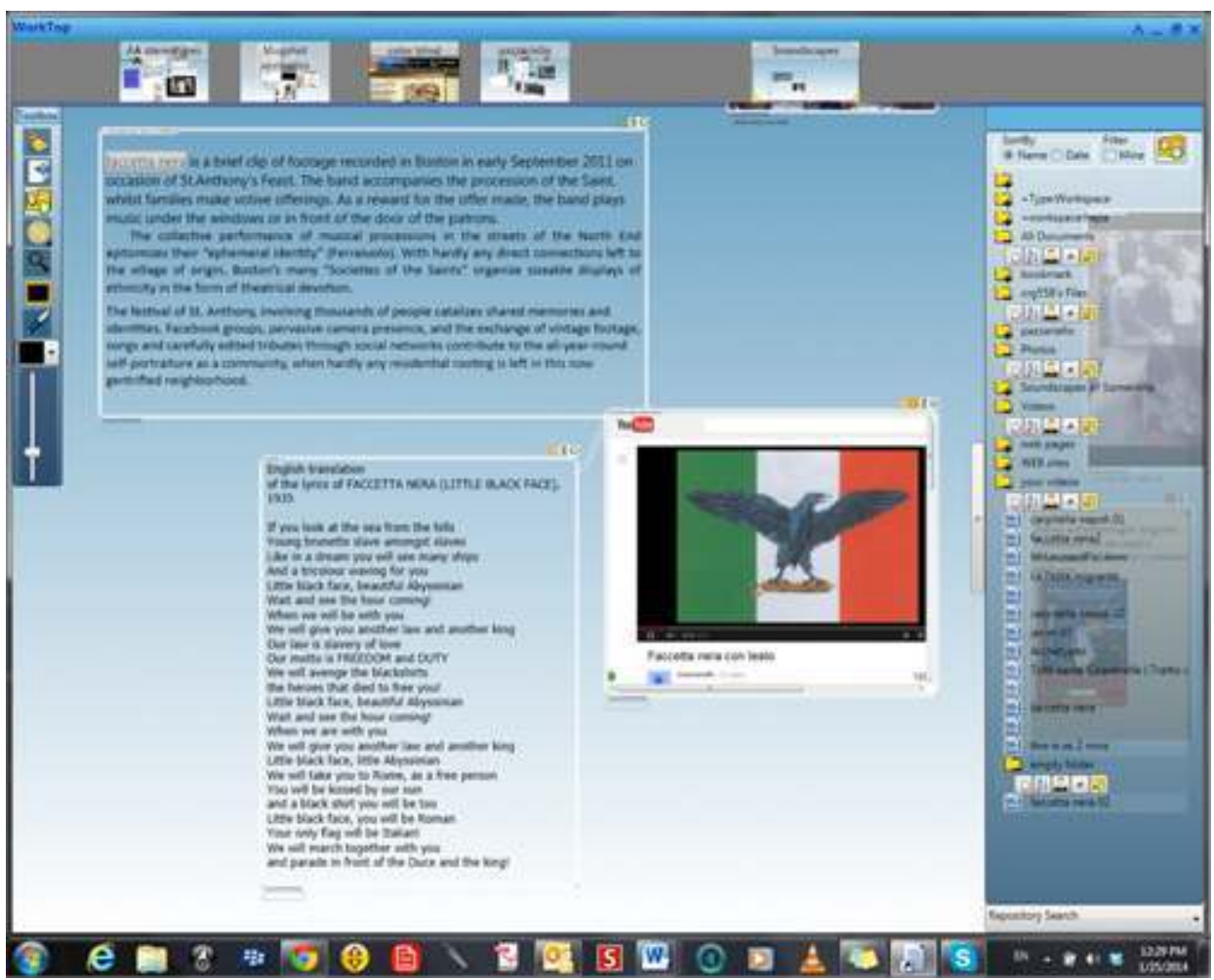

Faccetta Nera, found on Youtube (a vintage audio-record) with the lyrics in Italian and my own translation. The "Atlas" gathers some of the folk tropes that can be found in contemporary versions of the Feast and offers as many links and connections as possible, thus working in-depth and analytically - practically frame by frame. Many more materials were arranged and studied by me on the atlas without even making it into the film. Worktop, as a tool for analysis, could not provide a dynamic temporality to these annotations. On the other hand, the film Christmas in August offers a narrative of how some of these tropes are actively incorporated in a continuous exercise of selfnarration.

Screen snapshot by Cristina Grasseni

As Cornelia Zumbusch underlines (2010: 120): Warburg's Mnemosyne, usually read as a theory of cultural memory, is primarily a theory of pictorial quotation". The Atlas is thus not exhaustive, but (potentially infinitely) incremental. I believe that the metaphor of the Atlas is still generative for thinking ethnographically about visual engagements. The Atlas is a conceptual map that also serves as an inventory of potentially redundant, overlapping and divergent visual arguments. Present-day digital archives are potential Warburg-like atlases of conceptual imaginaries mediated though social networks, allowing one to arrange a series of visual argument in as many arcades, or tables, or nodes..$^{18}$ My own quest for "orientation" in cultural practice ${ }^{19}$ shares an interest for the analytic and synthetic capacity of the Atlas to draw out affinities and establishing linkages.

\section{Conclusion}

Some of the objects that attracted my attention were the similarities and anachronisms connecting cinematic icons of the 50s (such as the comedian Totò) with the folk tradition of the pazzariello recorded and analyzed by ethnomusicologist Diego Carpitella in 1970s 
Naples, with its contemporary adaptations and appropriation by token items and gestures in the Feast. Nevertheless, granted the circulation of recurrent gestures and figures I am not interested in the iconology of such figures, as much as in their social appropriation, their performance, and their capacity to create emotional value (attachment, identification, belonging) through sometimes paradoxical effects. Here, I simply intend to offer an argument about the complementarity of montage and the atlas as formal principles of representation. The former, Montage, allowed the meaningful rearrangement of found footage in narrative form (or rather I should say re-found footage, as I found it on Facebook - and traced those who put it up). ${ }^{20}$ In particular, the use of montage in the making the film allowed us to unpack a naturalized experience of the Feast as timeless, 'ethnic' token of popular religiosity - in other words, to enable a disruptive reading of 'religious festivals and patriotic songs' as objects opened to interpretation and debate. Thus the atlas provides a conceptual playground in which links can be established and made perspicuous, while montage is a rhetoric technique to contextualize and relativize, while also making relevant to the overall narration, the 'skilled vision' (or rather 'skilled listening') of the protagonists.

The pazzariello and Faccetta Nera are just two possible examples of the potentially infinite tropes of self-categorization, that are never neutral in their social appropriation. Ideally, a Skilled Visions Atlas could be a digitally annotated map of ways of looking, using ethnographic film making, web materials and archive sources. An epistemological complement to film-making, the digital archive can be imagined as a potentially infinite space that can be populated with film clips, photographs, articles, arranged side by side and organized into visual arguments or "nodes", annotated and tagged. The digital atlas is intended as a non linear device that allows to achieve an analytical overview of specific configurations, mining a collective imagination that continuously re-tells itself. Its corresponding and contrasting tool, when attempting to go back to film and provide a cinematographic sense of my digital archive, was necessarily montage.

Finally the issue of control and access over our own means of conceptualization, analysis and narration - as raised by other essays in this special issue and especially by Nadine Wanono and Gilles Remillet - should not be forgotten here. My collaboration to develop Worktop at Brown University was a constructive experience thanks to the patience of its developer. I was fortunate enough to show my database in an open event, followed by an exhibition generously organized by the Radcliffe Institute for Advanced Study at Harvard University at the end of my fellowship year. ${ }^{21}$ However, demonstration of the live database and software - which was in a phase of experimentation - at other sites such as at conferences or seminars, where a direct internet connection to the server hosting the database had not been previously established and tested, proved laborious due to technical issues. Finally the temporalities of research and of corporate software development are not necessarily in synch with each other. The database had largely been for me an intensive research "playground" for a specific period of time encompassing several months between 2012 and 2013, followed by investment on another fieldwork project. In the meantime its software development had been slowed down, and at the time of writing it had become "dormant".

For the purposes of this article, I have explored the implications of using film and the atlas as two complementary conceptual tools and representational strategies: the atlas is an analytic device (allowing to freeze visual materials, "zoom in" into details, establishing connections, and assembling materials of different nature and provenance in "visual 
nodes"). The film, Christmas in August, provides a synthetic and stereophonic presentation of some of those materials in a linear fashion that allows narration, using montage as its key principle of articulation. I have proposed the Atlas on the one hand and Montage on the other as two complementary formal principles that allow us to take full advantage of the dialectic nature of the sources we juxtapose here: on the one hand the analytics of a potentially infinite spatial expanse, on the other the storytelling allowed by film making; on the one hand annotation and cross referencing, on the other multiplicity of coexistent voices.

\section{BIBLIOGRAPHY}

Andall, Jacqueline and Duncan, Derek (eds.) 2005. Italian Colonialism: Legacy and Memory. Oxford and Bern: Peter Lang.

Andersson, Oscar. 2014. "William Foote Whyte, Street Corner Society and social organization", Journal of the History of the Behavioral Sciences, 50(1): 79-103.

Ballacchino, Katia. 2013. “Is Watching the Feast Making the Feast?” Anthrovision http:// anthrovision.revues.org/586

Bruno, Giuliana. 2002. Atlas of Emotion: Journeys in art, architecture, and film. New York; London: Verso.

Carpitella, Diego. 1973. Cinesica 1 : Napoli. 16mm film, Roma: Istituto Luce.

Carpitella Diego, 1981. “Cinesica 1. Napoli. Il linguaggio del corpo e le tradizioni popolari: codici democinesici e ricerca cinematografica”, La Ricerca Folklorica, No. 3, Special Issue: Antropologia visiva. Il cinema, pp. 61-70.

Chalfen Richard. 1986. "The Home Movie in a World of Reports: an Anthropological Appreciation", Journal of Film and Video, 38 (3/4): 102-110.

De Grazia, Victoria. 1981. The Culture of Consent: Mass Organisation of Leisure in Fascist Italy. Cambridge: Cambridge University Press.

De Grazia, Victoria. 1992. How Fascism Ruled Women: Italy, 1920-1945. Berkeley: University of California Press.

de Jorio, Andrea. 1832. La mimica degli antichi investigata nel gestire napoletano. Napoli: Stampatore del Fribreno. http://books.google.it/books?

id=NeQGAAAAQAAJ\&printsec=frontcover\#v=onepage\& $\& \mathrm{f}=$ false

De Musso, Federico and Grasseni, Cristina 2013. Christmas in August. Boston's St. Anthony's Feast. Video, 30 mins., https://vimeo.com/63213733

De Sica, Vittorio, Cesare Zavattini, Giuseppe Marotta, Dino De Laurentiis, Sophia Loren, Carlo Ponti, Silvana Mangano, Totò. 2001. L'oro di Napoli. Aurelio de Laurentiis Multimedia Home Video.

Efron, David. [1941] 1972. Gesture, Race and Culture. A tentative study of some of the spatio-temporal and "linguistic" aspects of the gestural behavior of Eastern Jews and Southern Italians in New York City, living under similar as well as different Environmental conditions. The Hague: Mouton. 
Faeta, Francesco. 1986. "Corpi, spazi, immagini. Appunti per uno studio di ex voto anatomorfi calabresi", in Emi de Simoni (ed.) Ex voto tra storia e antropologia, Roma: De Luca, pp. 69-96.

Feld, Steven. 2011. “Acoustemic Stratigraphies: Recent Work in Urban Phonography” Sensate Journal, http://sensatejournal.com/2011/03/steven-feld-acoustemic-stratigraphies/

Ferraiuolo, Augusto. 2009. Religious festive practices in Boston's North End: Ephemeral identities in an Italian American community. Albany: State University of New York Press.

Gibson, James J. 1979 The Ecological Approach to Visual Perception, Boston: Houghton Mifflin. Goodwin, Charles. 1994. "Professional Vision.” American Anthropologist 96: 606-33.

Grasseni, Cristina. 2007. Skilled visions : Between apprenticeship and standards. New York: Berghahn Books.

Herzfeld, Michael. 2005. Cultural intimacy: Social poetics in the nation-state. 2nd ed. New York: Routledge.

Ingold, Tim, 2000 The Perception of the Environment. Essays on Livelihood, Dwelling, and Skill. London: Routledge.

Kendon, Adam. 1995. "Gestures as illocutionary and discourse structure markers in Southern Italian conversation", Journal of Pragmatics, 23: 247-279.

McEwan, Dorothea. 2006. "Aby Warburg's (1866-1929) Dots and Lines. Mapping the Diffusion of Astrological Motifs in Art History". German Studies Review 29/2: 243-268.

Posen, S.I., Sciorra, J., Cooper, M. 1983. "Brooklyn's Dancing Tower: Brought to America by Immigrants from an Italian Town, the Feast of Saint Paulinus Celebrates Religious Devotion, Community Ties, and the Ideals of Manhood", Natural History, 92(6): 30-37.

Rampley, Matthew. 1999. “Archives of Memory: Walter Benjamin's Arcades Project and Aby Warburg's Mnemosyne Atlas”, in Coles, Alex. ed. The optic of Walter Benjamin. London: Black Dog Pub, pp. 94-117.

Rampley, Matthew. 2000. The remembrance of things past: On Aby M. Warburg and Walter Benjamin. Wiesbaden: Harrassowitz.

Saunders, Barry. 2008. CT Suite: the work of diagnosis in the age of noninvasive cutting. Duke University Press.

Sklar, Deidre. 2008. "Remembering Kinesthesia: an Inquiry into Embodied Cultural Knowledge", in C. Noland and S.A. Ness (eds.) Migrations of Gesture, Minneapolis: University of Minnesota Press, pp. 85-111.

Spinelli, Italo and Roberto Venuti. 1998. Mnemosyne : L'atlante della memoria di Aby Warburg. Roma: Artemide Edizioni.

Warburg, Aby, 2003. Der Bilderatlas Mnemosyne. Edited by Martin Warnke and Claudia Brink. Aby Warburg, 1866-1929. Gesammelte Schriften, vol. 2. Berlin: Akademie Verlag.

Whyte, William Foote. 1943. Street corner society: The social structure of an Italian slum. Chicago, IL: The University of Chicago Press.

Willerslev, Rane and Suhr, Christian. "Montage as an Amplifier of Invisibility", in Transcultural Montage, Oxford: Berghahn Books 2013.

Wittgenstein, Ludwig. 1954. Philosophical Investigations. London: Basil Blackwell. 
Zumbusch, Cornelia. 2010. "Images of history: Walter Benjamin and Aby Warburg”, in C.J. Emden and G. Rippl (eds.) Imagescapes. Studies in Intermediality. Peter Lang, pp. 117-143.

\section{NOTES}

1. Storytelling Engagements, AAA Executive Session Organized by Deborah Reed-Danahay (SUNY Buffalo) and Helena Wulff (Stockholm U), AAA 2013 Conference Theme: Future Publics, Current Engagements.

2. This is commonly considered a classic of the Chicago school of sociology, but recent scholarship insists on the many links between this research and his anthropological frequentations both at Chicago and at Harvard University (Andersson 2014).

3. According to Paul d'Amore, President of San Antonio Di Padova Da Montefalcione, Inc. (here referred to as St. Anthony's Society) at the time of filming, there were about 130 registered members of the society in 2012, of which about 50 were active and 9 had organizing tasks to actually run and fund the Feasts. He is originally from Montefalcione near Naples where the feast originates, though he has lived most his life in Boston, and at the time of film making he had been on the standing committee for the feast for 18 years (Paul d'Amore, Christmas in August, 2012).

4. Such as Northendwaterfront.com, also run and ideated by a member of the Society.

5. His work is in the public domain and easily available on line, and was reviewed and translated into English by Adam Kendon. Kendon (1995) claims that Carpitella did not offer any analysis of the conversations he filmed in Naples in the 1970s. Carpitella (1973) offered a cinematographic analysis of “communicative kinesics" following De Jorio's work and using Ekman-Friesen's gestural classificatory system - the same adopted by Efron in 1941.

6. See the extensive list of acknowledgements in the closing titles of the film itself as well as on the film web site: http://christmasinaugust.altervista.org/

7. The Royal March of the Savoy family is another regularly played motif (referred to as "Number One" in the film), which would be interpreted as reactionary in Italy. This was the national anthem under Italy's monarchy, until the king fled Rome in 1943 to join the advancing Allied forces in Naples, abandoning the national army and the rest of the country to civil war and German occupation. Because of this the royal family and descendants were, until very recently, banned from the Italian Republic.

8. See their course www.mediaarcheologyofplace. On the role of acoustic landscapes in the making of place, see Steven Feld's acoustemology project (Feld 2011).

9. Augusto Ferraiuolo has given a thorough historical reconstruction of Bostons's societies of the saints in his book tellingly subtitled Ephemeral identities in an Italian American Community (2009).

10. Ballacchino (2013) has studies the Gigli Feast at its original site in Nola as well as its candidature as UNESCO patrimony of humankind. For the Giglio in American urban contexts, see also Posen and Sciorra (1983).

11. Wittgenstein draws on the resemblances between members of a family to explain how we group together, say, different types of games (chess, baseball, hide-and-seek etc.) in one concept. He says that in family resemblance: "Build, features, eye-color, gait, temperament, overlap and criss-cross ... And we extend our concept as in spinning a thread we twist fibre on fibre. And the strength of the thread does not reside in the fact that some one fibre runs through its whole length, but in the overlapping of many fibres" $(1954, \S 67)$. 
12. Paul d'Amore explained that nowadays it costs so much to organize the feast, that without commercial sponsorship it would not be possible to put it up at the scale it has grown to.

13. About this process of collaboration, a joint article by De Musso and Grasseni is under review for this journal.

14. See https://www.radcliffe.harvard.edu/people/cristina-grasseni and http:// isites.harvard.edu/icb/icb.do?keyword=k87821\&pageid=icb.page508106

15. „Die Wanderstrassen der Kultur“, Mc Ewan 2006.

16. In pursuing the Passagen-Werk, Benjamin had planned an historico-cultural study of Paris in the Second Empire with emphasis on the products and self-presentation of the high-capitalist commodity culture" (Zumbusch 2010: 119).

17. Worktop was at the time (2012-2013) being developed for Microsoft Research at Brown University: http://cs.brown.edu/research/ptc/worktop/index.html

18. This language intentionally evokes the exploratory work of Walter Benjamin on urban visualism and of Aby Warburg on the iconology of visual tropes.

19. On his death bed, Warburg is reported to be reacting to Kant's essay "What does it meant to orient oneself in thought (was heist: sic him Denken orientieren?)" and to have noted down Was bedeutet, sich im Raum zu orientieren?. See McEwan 2006.

20. In a joint article under review for this journal, Federico De Musso and myself develop a joint reflection on the methodological scope of montage in researching social networks for our film, Christmas in August.

21. The Exhibition Opening Seminar, "Skilled Visions: Critical Ecologies of Belonging" was held on 17 April 2012 at the Radcliffe Institute for Advanced Study in collaboration with the Harvard Film Study Center, with the participation of Bob Zeleznik, Director of Research at Brown University's Graphics, Visualization, and Interaction Group, to whom I am grateful for his engaged and patient commitment to this project over several months.

\section{ABSTRACTS}

In this article I refer to my fieldwork in Boston's North End to explore the implications of using film and media annotating software as two complementary conceptual tools and representational strategies. I elaborate on Warburg's notion of the "atlas" as an analytic device. I propose the Atlas on the one hand and Montage on the other as two complementary formal principles that allow us to take full advantage of the dialectic nature of the sources we encounter in visual ethnography, as well as of our own capacity for visual engagement: on the one hand a potentially infinite analytics, on the other our own storytelling engagement through filmmaking.

En este artículo me refiero a mi trabajo de camo en el North End de Boston para explorar las implicaciones que conlleva el uso de software de anotación de cine y de media en tanto que herramientas conceptuales y estrategias representacionales complementarias. Elaboro mi reflexión a partir de la noción de "atlas" de Warburg, que tomo como dispositivo analítico. Propongo el Atlas y el Montaje como dos principios formales complementarios que nos permiten sacar pleno provecho de la naturaleza dialéctica de las fuentes que encontramos durante la etnografía visual, así como de nuestra propia capacidad para interaccionar visualmente (visual 
engagement): por un lado, un análisis potencialmente infinito, y por el otro lado nustro propio compromiso narrativo a través de la práctica cinematográfica.

Dans cet article, je fais référence à mon travail de terrain, réalisé à Boston, afin d'explorer les implications inhérentes à l'utilisation de deux outils conceptuels complémentaires le film et les logiciels d'annotations qui ensemble favorisent les stratégies de représentation. Je développe la notion d'Atlas proposée par Warburg comme un outils d'analyse. D'un côté, je propose l'Atlas et de l'autre le montage comme deux principes formels qui nous permettent de saisir pleinement la nature dialectique des sources que nous rencontrons en ethnographie visuelle ainsi que dans le cadre de nos propres compétences visuelles: d'un côté une analyse au potentiel illimité et de l'autre nos propres capacités à raconter des histoires à travers la réalisation filmique.

\section{INDEX}

Mots-clés: Atlas, Boston, base de données, réalisation, engagement, analyse, Warburg

Keywords: Atlas, Boston, database, film-making, engagement, analytic, Warburg

Palabras claves: Atlas, Boston, base de datos, realización fílmica, compromiso (engagement), analisis, Warburg

\section{AUTHOR}

\section{CRISTINA GRASSENI}

Utrecht University

Cultural Anthropology

c.grasseni@uu.nl 